\title{
Structure with controllable permeability for vertical aerodynamic stabilizers-decelerators
}

DOI: 10.35530/IT.069.02.1530

\section{REZUMAT - ABSTRACT}

\section{Structura cu permeabilitate controlabilă pentru stabilizatoare-deceleratoare aerodinamice verticale}

Problemele științifice și tehnice legate de aplicațiile materialelor high-tech în ansamblul sistemelor de recuperare sunt deosebit de numeroase și variate. Ansamblul parașutei reprezintă cea mai importantă parte a unui sistem de recuperare, ceea ce impune o cunoaștere aprofundată a caracteristicilor de performanță în condițiile în care acestea reprezintă elemente decizionale în selectarea și proiectarea acestui sistem deosebit de complex. În acest context, lucrarea prezintă principalele realizări în domeniul proiectării și realizării structurilor destinate stabilizării-decelerării munițiilor din dotarea divizioanelor de luptă.

Cuvinte-cheie: sistem de stabilizare-decelerare, muniție, analiză structurală, calcul parametri de structură

\section{Structure with controllable permeability for vertical aerodynamic stabilizers-decelerators}

The scientific and technical issues related to the high-tech materials applications in the recovery systems ensemble are very numerous and varied. The parachute ensemble represents the most important part of a recovery system, and therefore this fact requires a thorough knowledge of the performance characteristics as they are the decision-making elements in the selection and design of this extremely complex system. In this context, the paper presents the main achievements in the field of designing and realizing the structures for the stabilization-deceleration of the combat divisions' ammunition.

Keywords: stabilization-deceleration system, ammunition, structural analysis, structure parameters calculation

\section{ACHIEVEMENTS AND PERSPECTIVES IN THE FIELD OF DECELERATING SYSTEMS}

\section{History}

Any air vehicle (considered as main system) contains the following: the propulsion system, the guidance system, the fuselage and the wings and the recovery system. The recovery system has as its components, alongside the recovery system by means of the parachute, interclassing, impact mitigation, flotation, locating, stabilizing and coupling equipment (for space vehicles) [1]. A recovery system by means of the parachute specific to supersonic aircraft and spacecraft has the following components: the airplane hold, and, apart from this compartment, the extractor parachute trigger system, the airplane link cord, the hangers, the main parachute and the case. For the ejection seat parachute ensemble, for example, the components are these: the harnesses, the binding cord, the hangers, the canopy, the main parachute case, the braking parachute, the extraction cord and the ejection seat (there may be variants of this: the main independent parachute, the altitude stabilizer braking parachute, the reactions control system RCS, the sensors for the seat stabilization) [1]. By definition, a parachute is a device designed to increase the drag of a body moving in a fluid. Since this fluid is the air, we can consider that a parachute is a particular case of "air brake" [1]. In most applications, the force that propels the body is its own weight so that the weight of the device that provides resistance has to be very low. From this viewpoint, the parachute can provide a high drag, with a very low added weight $(8-12 \%)$ [1]. The military parachute is an ensemble consisting of elements which, functioning together, ensure for a given mass conditions of controlled descent, braking and stabilization as well as: the automatic opening, the parachute deployment, the loads support and the drag.

The first account of a parachute dates back to 2258-2208 BC when, a Chinese manuscript reports about the escape of Sun, the emperor of China - and the first parachutist in history - from a high tower with the help of two parachutes with which "he gets to the ground easily, without getting hurt" [2]. Leonardo da Vinci made the first sketch of a parachute during 1480-1483 (figure 1). The first successful test of a parachute was performed in 1617 in Venice by Dalmat Faust Vrančić.

The first military uses of the parachute were made by the artillery observation balloons operators during the First World War. These balloons were tied to the ground, being safe targets for the enemy airplanes, despite the strong anti-air defense [3]. The first jump with commanded opening was executed in 1919 by the Frenchman Lallemand, and the American Leslie Irving, performed the first jump with delayed opening, 


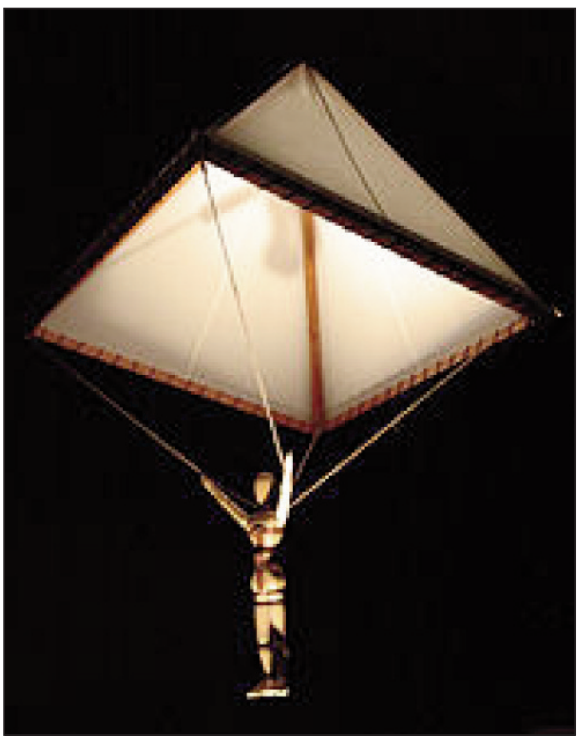

Fig. 1. Model of the parachute designed by Leonardo da Vinci (1480-1483)

after 400 meters of free fall. In the early 1920s, the plane, circular parachute, made of continuous textile material (the solid parachute), was the first parachute used to save aviators, to do sports and to parachute small loads [4]. Since 1930, the armed forces have begun to use parachutes for the deployment of airborne troops and heavy loads and for aircraft braking. Starting with 1940, the parachutes have been used to recover unpiloted planes, missiles, artillery ammunition, and later, these have also been utilized to recover piloted or unpiloted spacecraft [2-4]. The parachutes developed so far are superior to the plane - circular ones in terms of stability, opening force and drag. Some of the current parachutes can be used for supersonic applications, others for gliding descent (paragliders) [4]. However, only one type of parachute cannot provide superior performance in terms of aerodynamic characteristics.

The limits of recovery systems by means of parachutes in applications domains

Further developments have led to the conclusion that the recovery systems by means of the parachutes can be used for the following:

The airborne deployment of military personnel, equipment and technology in the final phase of transportation to the operations theater. Under these circumstances, the personnel have to be unharmed and ready for action and the equipment, intact and ready for use (figure 2). The parachutes for saving lives in air vehicles, although they are disposable (if the jump is unpremeditated) or have a limited number of uses (for premeditated jumps), must ensure extremely high functioning safety and a long-lasting technical resource (10-16 years). The parachute for airborne troops has to satisfy complex conditions (figure 3).

Such a parachute not only has to save life but to deploy a man who has been instructed to jump with equipment, to land in good conditions and to be ready to fight. In this situation, the descent speed
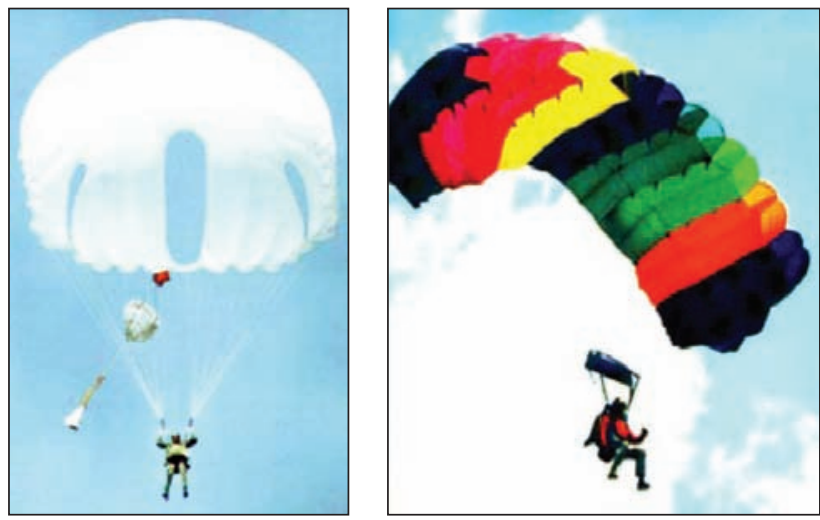

Fig. 2. Parachute for crew descent - rescue (Photo by courtesy of SC CONDOR SA) [1]

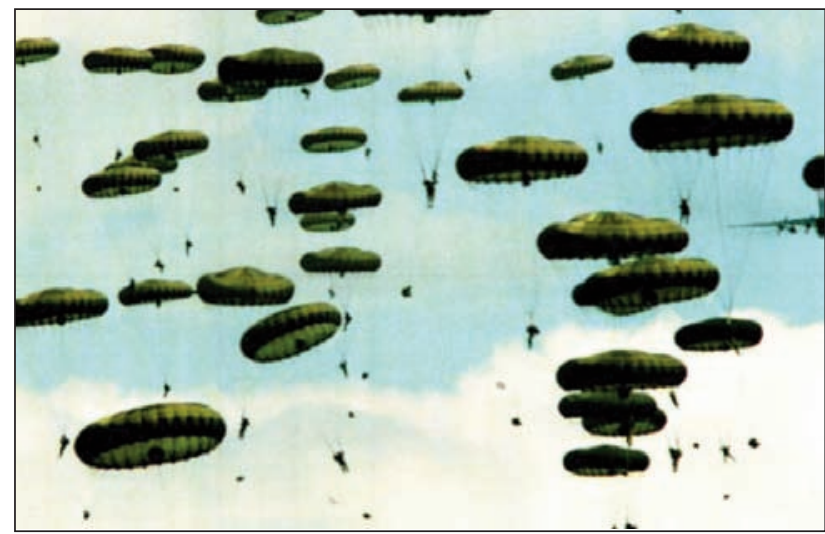

Fig. 3. Parachute for airborne troops deployment (Source: IRVIN AEROSPACE LTD)

must be reduced, and this can be done by using a larger diameter parachute.

The parachuting of military equipment and technology may involve deploying weights of hundreds or thousands of pounds (figure 4 and 5). Under these
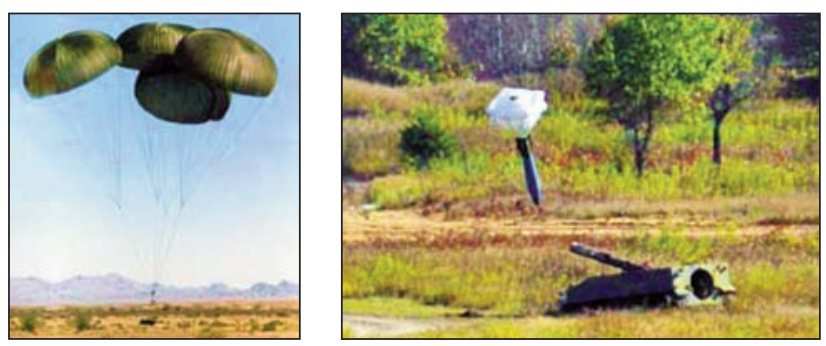

Fig. 4. Parachutes system for military equipment descent [2]

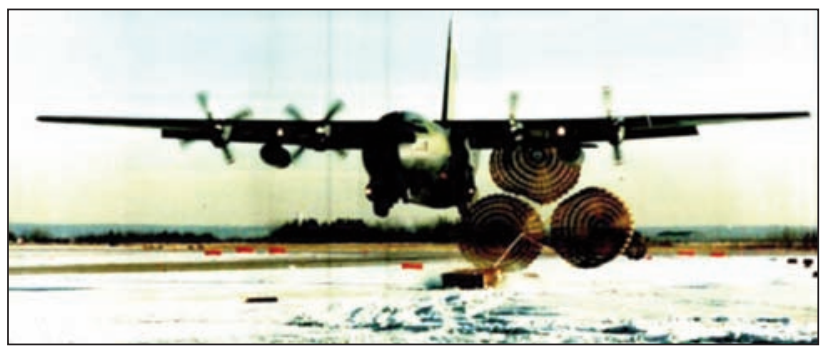

Fig. 5. Low altitude parachutes extracting system (LAPES) (Source: IRVIN AEROSPACE LTD) [1] 

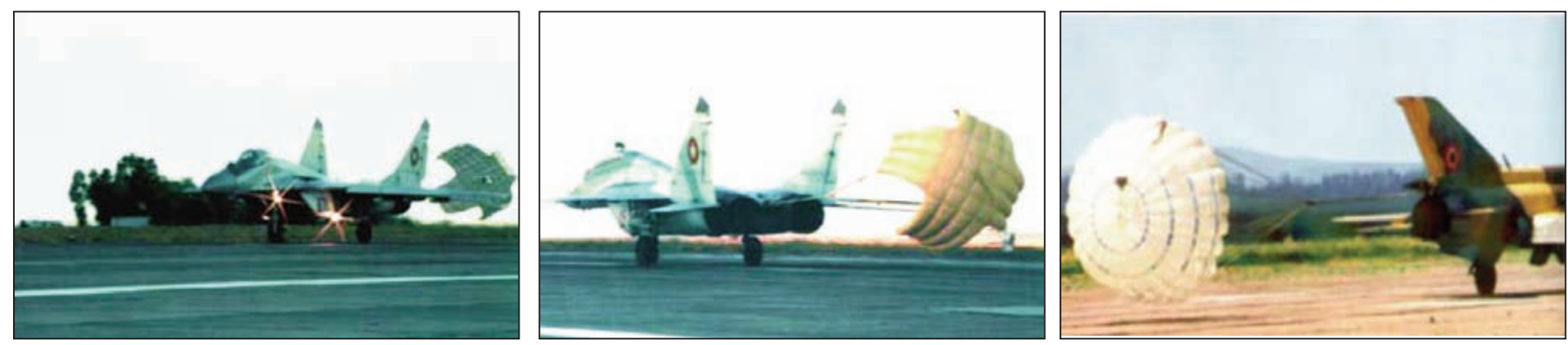

Fig. 6. Parachute for braking at landing MiG 29 and MiG 21 LanceR supersonic aircraft (Photo by courtesy of SC CONDOR SA) [1]

conditions, the dimensions of these parachutes vary considerably, and in case the load is very high, we can use a parachute beam that opens simultaneously [5-6].

The stabilization and braking of aircraft during military operations. The first known attempt using a parachute as a landing brake was made in 1923 by means of a standard parachute for humans to reduce the landing of a Havilland biplane [7].

Currently, the stabilization of a combat aircraft is done by means of the parachute during its dangerous maneuvers: spin, stalling (at low incidence angles), wings vibration (at very high speeds). For these critical situations, the parachute is deployed and the aircraft has a normal flight attitude. Braking is used when the aircraft is in flight or is landing to reduce the braking distance, and also to protect the brakes and wheels. Worldwide, two types of braking parachutes are known, namely: - for aircraft braking and control during flight, known as the approach parachute; - for aircraft braking at landing, known as the braking parachute at landing (figure 6). This type of parachute is used, along with the aerodynamic and mechanical devices (the flaps, the aerodynamic brakes, the spoilers, the lift-dampers) to brake the aircraft during running at landing, thus producing the highest braking force at the speed with which the plane touches the ground, when the brakes are virtually ineffective [1]. Besides reducing the landing distance, the system provides increased flight safety under conditions of risk (for example during landing with non-operating brakes), during unsuccessful take-offs, during forced landings on short runways and on ice-covered or wet runways [1].

The weapons delay to enable the plane to adjust the firing, to stabilize and delay the artillery ammunition before entering the water (figures $7,8,9,10$ ) to obtain
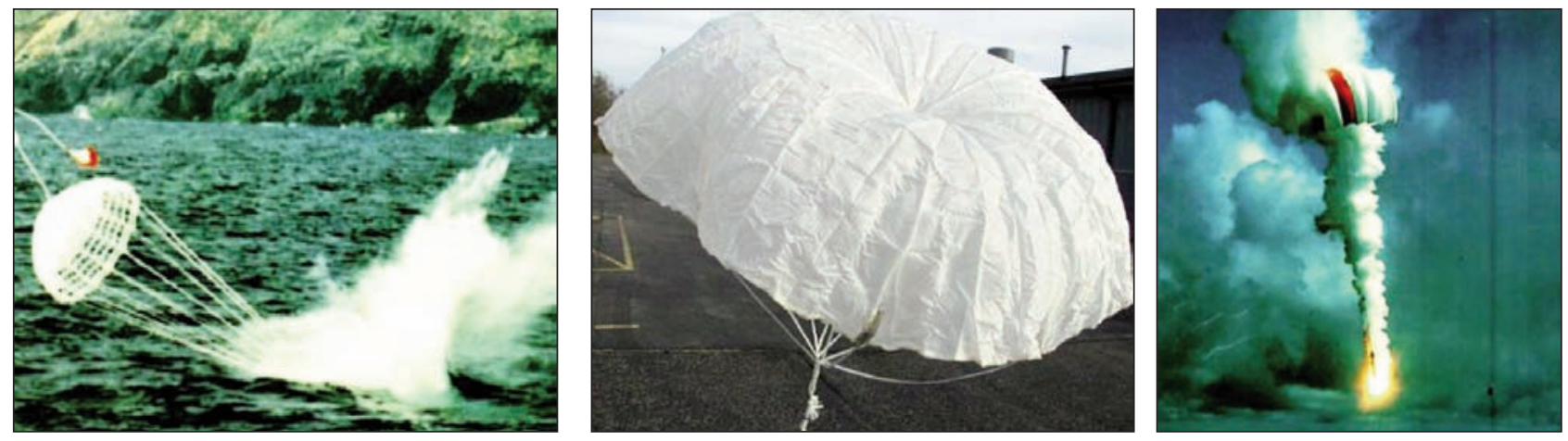

Fig. 7. Parachute for torpedoes and mines deceleration (Source: IRVIN AEROSPACE LTD) [1]
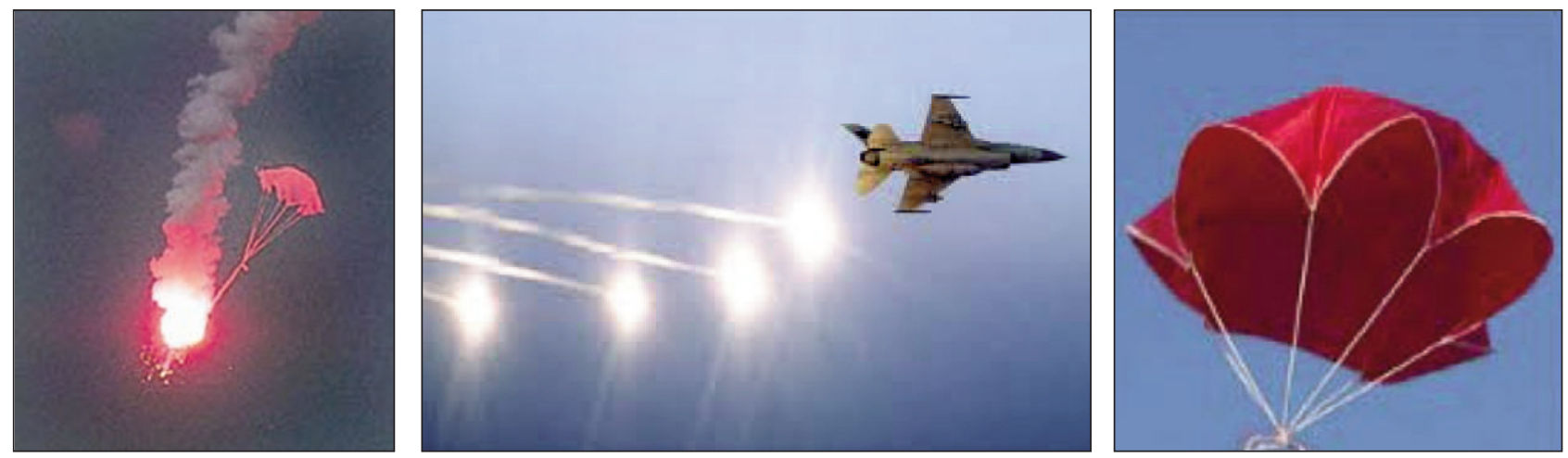

Fig. 8. Parachute for ammunition delay - braking - stabilization [2] 

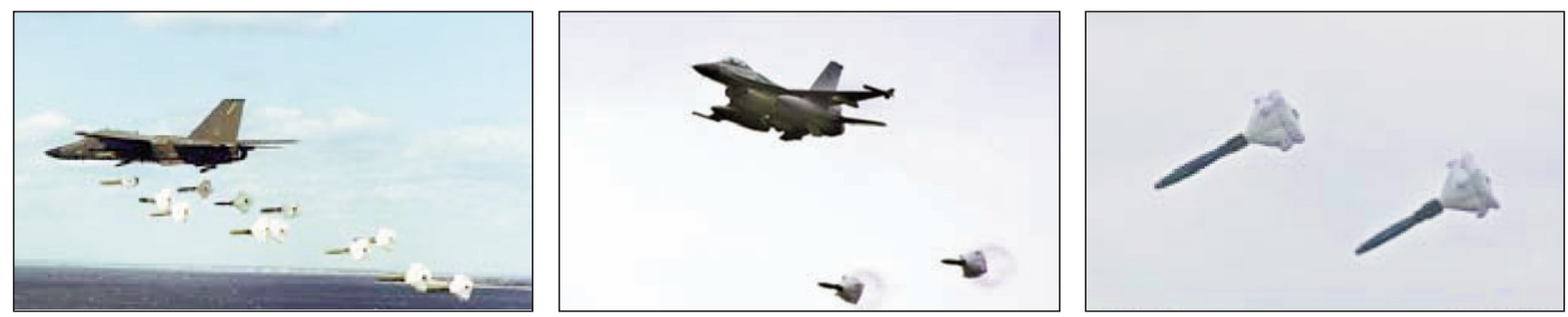

Fig. 9. Parachute for weapons BSU-49/BSU-85 [2]

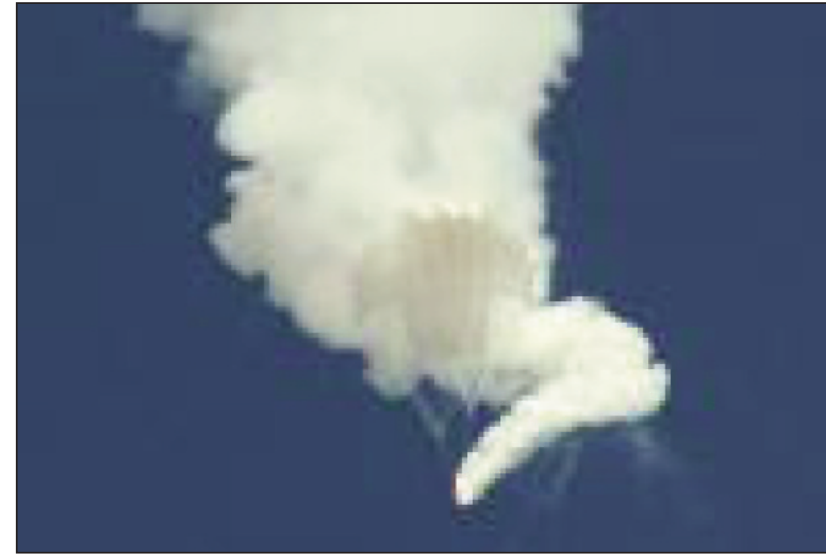

Fig. 10. Parachutes for lighting projectiles (Courtesy of SC CONDOR SA)

the desired impact angle and an ordered distribution of the shrapnel. The parachutes used to launch fire and explosive bombs have a simpler construction than the other types and are made of easily accessible materials.

Recovery of Targets, Unpiloted Systems, Unmanned or manned boosters and Spacecraft. This operation is done by means of special MARS (Midair Retrieval System) parachutes (figure 11). Until 1950, parachute applications were closely related to the aircraft speed and capability to fly at high altitudes [1]. Subsequent research has established that parachutes can be successfully used at speeds higher than 4 Mach at an altitude beyond the atmospheric boundaries and at a dynamic pressure of $15,000 \mathrm{psi}\left(21.3 \mathrm{~kg} / \mathrm{m}^{2}\right)$ [8] and can therefore be used at recovering boosters with a mass higher than 185,000 pounds $(83,914 \mathrm{~kg})$. The variations in these values are in close connection with the new types of raw materials and materials that appear.

Developments in this regard have led to the emergence of high performance parachutes that have been successfully used on Mars, and there are currently special preparations to recover the space capsules which will fly to Venus and Jupiter [1].

The Pioneer Venus probe was designed to study from the planet, the atmosphere composition of the telluric planet Venus (figure 12).

While entering the planet's atmosphere, the aerodynamic forces exerted on it were calculated for a level
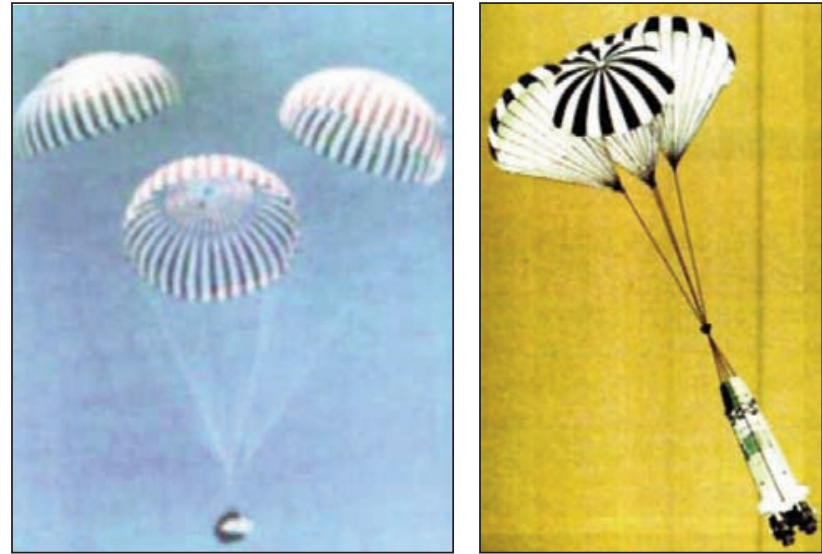

Fig. 11. Parachute for spacecraft descent, space capsules and modules planetary descent-braking [7]

of $300 \mathrm{~g}$. In addition, to be able to into account the braking of the probe, it was necessary to also consider the planet's atmosphere (sulfuric acid).

The theoretical foundation for the construction of vertical deceleration systems

The theoretical foundation for constructing the stabilization-deceleration systems was based on the theories of both Fluid Mechanics, related to: the rapid variable transient motion, the continuity hypothesis, the physical properties of the fluids, the equations of a continuous medium movement, the boundary layer, the turbulent movement, as well as Aeronautics, related to the flow of fluid around a sphere. In this regard, we considered important that the fluid is

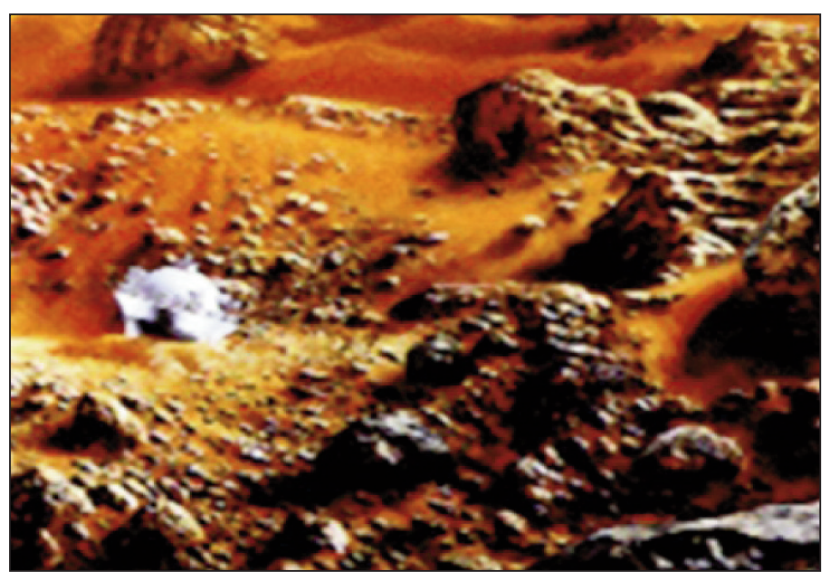

Fig. 12. Pioneer Venus Probe - NASA [1] 


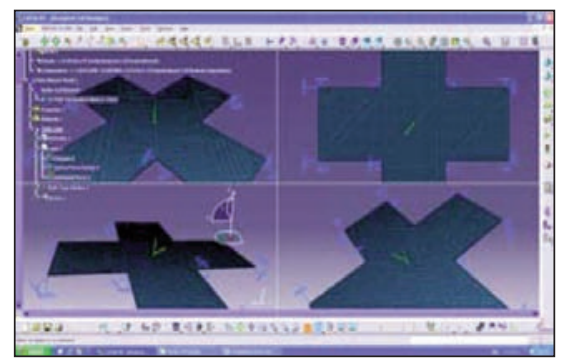

a

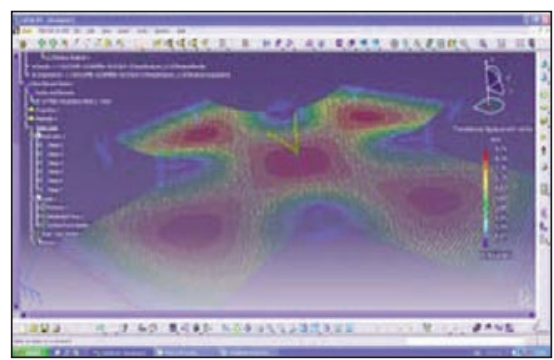

b

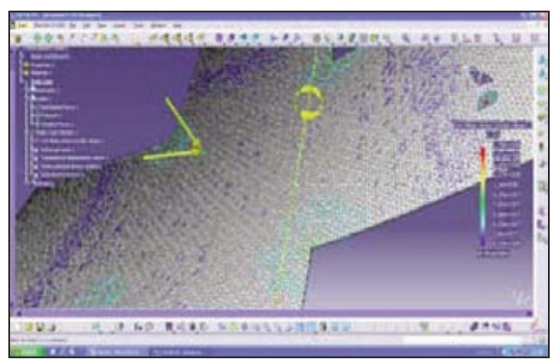

c

Fig. 13. $a$ - the deformation of the canopy for ammunition with the mass of $4.32 \mathrm{~kg} ; b$ - the distribution of displacement vectors for ammunition with the mass of 3-50 kg; $c$ - representation of the Von Mises stress (nodal values) for ammunition with the mass of $80-500 \mathrm{~kg}$

incompressible and the flow occurs in a turbulent regime. In order to design the functional model of the stabilization-deceleration system's canopy, we carried out three structural analyzes - with the assistance of specialized software - for three distinct situations, required by: the technical and tactical conditions of use (the mass, the launch height: $300-1100 \mathrm{~m}$; the propulsion speed: $140-650 \mathrm{~m} / \mathrm{s}$ ), the effects after launch (shrapnel and shock wave), the range of the operating temperatures: $\left(-40^{\circ} \mathrm{C} \ldots+70^{\circ} \mathrm{C}\right)$ the range of action (300-800 m), the propulsion type: selfdestruction with $6 \mathrm{~s}$ delay, the illumination surface (400-800 m), the illumination intensity (200000$900000 \mathrm{~cd})$, the burning-illumination time (25-45 s), the maximum force at which the canopy has to resist: $3125 \mathrm{~N}$. Through the included solver, during the postprocessing stage, we saw the phenomena occurring on the canopy, which allowed us to determine the variation intervals of the structural parameters. The structural analysis performed in the three situations was based on the theories of the continuous mediums mechanics. We considered that the canopy is a continuous medium that fills a certain area of space, so that at each of its geometric points, there is one material point of the medium. The geometry of the main parachute of the stabilization-deceleration system was discretized in a different series of finite elements, depending on the technical-tactical characteristics of the ammunition to be stabilized-decelerated, with the elemental mass $\Delta \mathrm{m}$, in which the continuity property required the existence of the mass density. We took into account the actual exploitation conditions that imposed to consider the medium as being elastic, since there is no deformation after the stabilization-deceleration, the canopy returning to the initial condition. The resulting values: following the structural analysis for: the canopy deformation, Von Mises stress, the displacement vectors, the estimated error distribution (for all the three studied situations), as well as those resulting from the use of the theory without moments, allowed us to determine the main structural parameters required for the design of the structure with controlled permeability used as the canopy of the aerodynamic stabilization-deceleration system. Figure 13 shows the different stages of the structural analysis performed for the canopy as stabilization-deceleration system for ammunition with the mass of: $4.32 \mathrm{~kg}, 3-50 \mathrm{~kg}$ and over $80 \mathrm{~kg}$, respectively.

In order to determine the main structural parameters of the fabric for the canopy, we considered the following calculation assumptions:

- the stability in operation: oscillation angle of max. $\pm 30^{\circ}$; drag coefficient $c_{x}: 0.60-0.85$; low shock at opening: shock coefficient at opening $c_{s}=1,1-1,2$; low mass and volume: $3-5 \%$ from the mass of the ammunition subjected to braking.

- the ultimate load coefficient (composed of: the safety coefficient, the dynamic load coefficient, the nonsymmetric load coefficient, the coefficients due to the joints, the fatigue and the environmental factors) which affect the canopy of the deceleration parachute.

The calculations have led to the conclusion that the chosen density of both warp and weft systems is of 390 yarns $/ 10 \mathrm{~cm}$.

\section{CONCLUSIONS}

The paper presents the main achievements in the field of the structures used for the stabilization-deceleration systems of the military devices and ammunition. The theoretical foundation of the phenomena occurring on the canopy of the system was made with the assistance of specialized software that allowed us to highlight the following aspects: the canopy deformation, the displacement vectors distribution, Von Mises stress. The data obtained together with the requirements imposed on such a stabilization-deceleration system allowed us to determine the structural parameters for the fabric used for its construction. 


\section{BIBLIOGRAPHY}

[1] Mihai, C. Theoretical and practical contributions to the design and production of technical articles woven for aviation, Doctoral Thesis - 2004 .

[2] *** http://www.rumaniamilitary.ro/

[3] Brown, W.D. Parachute, vol. I, II, Londra, 1949.

[4] Knacke, T.W. Parachute recovery systems, Para Publishing, Santa Barbara, California,1992.

[5] Knake, T.W. Techical-historical development of parachutes and their applications since World War I AIAA, Paper No. 86 - $24239^{\text {th }}$ Aerodynamic Decelerator and Balloon Technology Conference, Albuquerque, 1986.

[6] *** Irvin Aerospace Ltd. Marea Britanie, 2000.

[7] Sanger, M.B. Jr Summary od design consideration for airplane spin-recovery parachute systems, NASA, 1972 (Report NASA-TN-D-6866).

[8] Rodier, R.W., Moog, R.D., Kross, D.R. 136-Foot Main Parachute for recovery of Space Shuttle Solid Rocket Boosters, American Institute of Aeronautics and Astronautics, 1984 (AIAA 84-0804).

\section{Authors:}

Eng. Mat. PhD CARMEN MIHAI ${ }^{1}$

Eng. Attorney PhD ALEXANDRA ENE ${ }^{1}$

Seng. CRISTIAN JIPA ${ }^{1}$

Stud. CARMEN DENIS GHIMUS ${ }^{2}$

${ }^{1}$ The National Research \& Development Institute for Textiles and Leather

${ }^{2}$ City University of London, Department of Mathematics

Corresponding author:

\section{CARMEN MIHAI}

e-mail: carmen.mihai@certex.ro

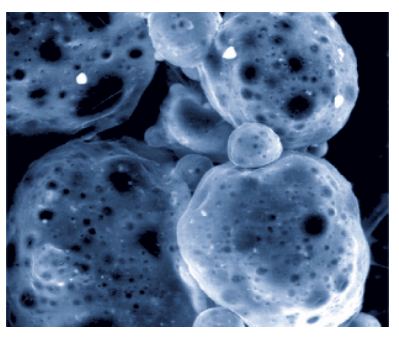

